\title{
First Record of Teratopactus nodicollis (Coleoptera: Curculionidae) in Dry Bean (Phaseolus vulgaris)
}

\author{
ED Quintela ${ }^{1}$, JaP dos Santos $^{2}$, JAF Barrigossi ${ }^{1}$, JVC Guedes ${ }^{3}$ \\ ${ }^{1}$ Embrapa Arroz e Feijão, Santo Antônio de Goiás, GO, Brasil \\ ${ }^{2}$ Projetar Ltda, Unaí, MG, Brasil \\ ${ }^{3}$ Depto de Defesa Fitossanitária, Univ Federal de Santa Maria, Santa Maria, RS, Brasil
}

\section{Keywords}

Bioecology, metarhizium, naupactini, root pest, weevil

\section{Correspondence}

Eliane Dias Quintela, Embrapa Arroz e Feijão, Caixa Postal 179, Santo Antônio de Goiás, Goiás 75375-000, Brasil; quintela@cnpaf.embrapa.br

Edited by Roberto A Zucchi - ESALQ/USP

Received 11 January 2011 and accepted 2 March 2012

Published online 4 May 2012

(C) Sociedade Entomológica do Brasil 2012

\begin{abstract}
Observations on the bioecology and damage of Teratopactus nodicollis Boheman on Phaseolus vulgaris were carried out on field samples by assessing the number of larvae and root damage in 40 ha of a dry bean field from the Federal District, Brazil $\left(16^{\circ} 4^{\prime} 28.41^{\prime \prime} \mathrm{W} ; 47^{\circ} 30^{\prime} 21.13^{\prime \prime} \mathrm{S}\right)$. Larvae caused the greatest damage at the stage of germination, emergence, and primary leaves, producing $50 \%$ stand reduction. Most larvae pupated in August and September, and adult emergence occurred in middle October. Some larvae were infected with the fungus Metarhizium spp., a biological agent that would be naturally controlling this insect.
\end{abstract}

The root weevil Teratopactus nodicollis Boheman is widespread in South America, occurring in Brazil, Argentina, Bolivia, Paraguay, and Uruguay (Lanteri et al 2002, del Rio et al 2006). In Brazil, it has been associated with Citrus spp., corn, potatoes, and grapes (Lanteri et al 2002, 2003) and with the native plants Baccharis dracunculifolia, Panicum campestre, and Paspalum plicatum (Silva et al 1968). We have been observing $T$. nodicollis causing damage to dry bean (Phaseolus vulgaris) since 1995, in Unaí, state of Minas Gerais, but no record has ever been published. In 1998, an outbreak occurred in 30 ha of a dry bean field, under irrigation by center pivot. Since 1999, several drybean producing areas have been damaged by this insect in the Federal District, Cristalina (Goiás), and Unaí (MG). The main objective of this investigation was to report the first occurrence of this species on dry beans in Brazil.

The observations were done in a dry bean plantation of $40 \mathrm{ha}$, located at Veredas farm $\left(16^{\circ} 4^{\prime} 28.41^{\prime \prime} \mathrm{W} ; 47^{\circ} 30^{\prime} 21.13^{\prime \prime}\right.$ S), Federal District, on oxisol (dark red latosol) soil. The dry bean cultivar BRS Pérola was seeded in $0.45 \mathrm{~m}$ rows on July 12, 2001. Conventional tillage with two plowing and two harrowing was used, and irrigation to the plants was provided by a center pivot. The samples analyzed for root damage were taken in July-August of 2001 (July 3, July
26, August 2, August 9, August 16, and August 23) from 15 sample sites $(100 \times 30 \times 10 \mathrm{~cm})$. The collected larvae found were placed into cylindrical plastic containers $(4.0 \times 5.0 \mathrm{~cm})$ filled with soil and covered with a nylon screen and taken to the laboratory for the assessment of larval development and larval mortality induced by parasitization and diseases. Larvae were held in white plastic cups $(11 \times 8 \mathrm{~cm})$ containing dry bean plants at the stage of primary leaves grown in soil collected at the Veredas farm. To determine the time required for adult emergence, field observations were done on a weekly basis from July to October of 2001. The specimens collected were identified by one of us (JVCG) and deposited at the collection of the "Depto de Defesa Fitossanitária, Univ Federal de Santa Maria, Santa Maria, Rio Grande do Sul."

The short-nosed weevils are about 15-20 mm long and covered with a gray to brownish vestiture (Fig 1a). Pronotum with one tubercle on the middle of each flank and humeri with distinct tubercles. Three pairs of tibiae with a line of denticles on the inner surface, those of fore tibiae, strong (Guedes et al 2005). Most larvae were collected at $6 \mathrm{~cm}$ deep in the soil, although several of them were found near to the soil surface, or deeper when near pupation.

Plants damaged by the insect were dry, wilt, or death. Larvae caused greater damage at germination, emergence, 
Fig 1 Teratopactus nodicollis. a Adult; $\mathbf{b}$ typical damage caused by larvae on dry bean roots at the stage of primary leaves (a transverse cut at the end of the tap root).
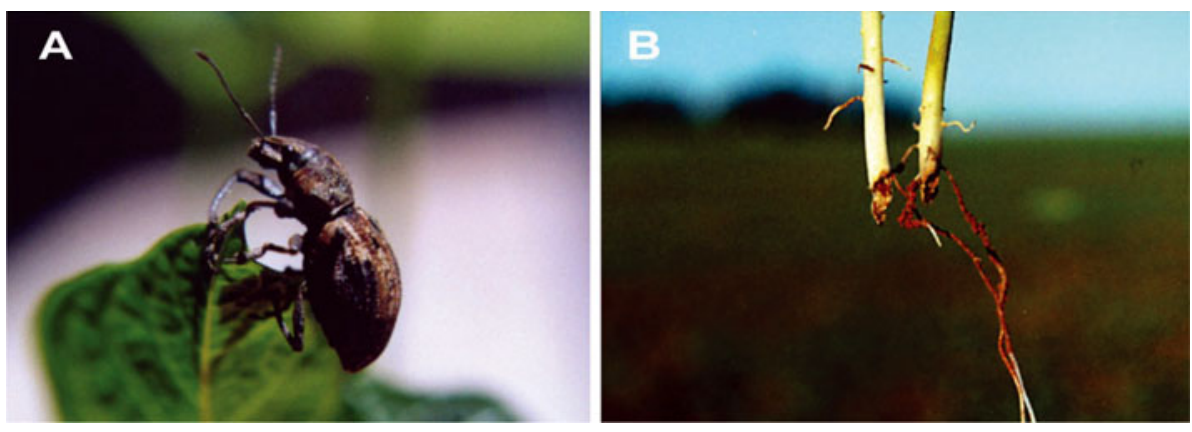

and at stage of early vegetation growth. When larvae fed on the radicle and hypocotyle, the plants died before emergence, producing gaps along the rows in the field.

At the stage of primary leaves, larvae cause a typical injury characterized by a transverse cut at the end of the tap root (Fig 1b). Some plants produce lateral roots to compensate the loss of the main root. The death of the plants usually occurs in latter stages of development, especially when the need of water and nutrients increase, and there is only one side of the main root. In growing plants, the larvae feed on the cortex of roots, preventing their development. The attack of $T$. nodicollis was aggregated, causing evident reduction in plant density with an average of only six plants per meter (Fig 2), which produced a $50 \%$ reduction in the plant stand as compared to the 12 plants per meter observed near the pivot area, where plants were not infested.

Larval mortality within a given sample increased over time (Fig 2) probably due to natural factors, such as the excess of humidity or infection by a biological agent as the pathogenic fungus Metarhizium spp. Of the 38 larvae brought to the laboratory, 11 died for unknown reasons and two by Metarhizium spp. This entomopathogenic fungus appears to be the most prevalent microbe infecting insects inhabiting soil worldwide (Beavers et al 1983, McCoy et al 1996, Quintela \& McCoy 1998). In the laboratory, most of the larvae pupated between August and September, and adult

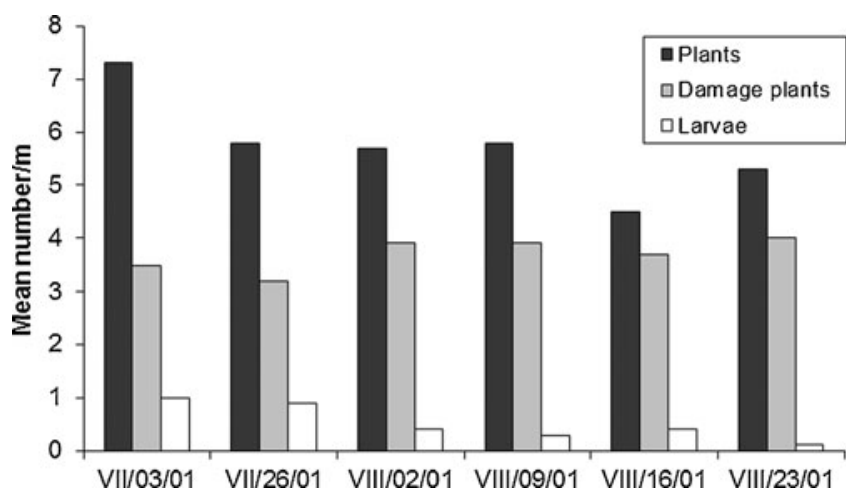

Fig 2 Mean total number of plants per meter, mean number of damaged plants per meter, and mean number of Teratopactus nodicollis larvae per meter in a dry bean cultivar BRS Pérola under center pivot, at different sampling dates. emergence occurred in October, at the same time as in the field (middle October).

The recognition of larvae, pupae, and adults and the characterization of the damage of $T$. nodicollis to dry beans are important to monitor the dispersal and development of this insect in the production systems from Brazil. For an efficient management of this insect pest, it will be also necessary to gather more information on its biology, behavior, population dynamics, host plant associations, and factors that affect population growths.

Acknowledgments We are thankful to José Francisco Arruda e Silva and Dalva de Fátima Bastos Gonçalves for their assistance in the samplings and maintenance of the larvae and to the Conselho Nacional de Desenvolvimento Cientifico e Tecnológico (CNPq) for the financial support (grant 520824/98-9).

\section{References}

Beavers JB, McCoy CW, Kaplan DT (1983) Natural enemies of subterranean Diaprepes abbreviatus (Coleoptera: Curculionidae) larvae in Florida. Environ Entomol 12:840-843

Del Rio MG, Lanteri AA, Guedes JVC (2006) Taxonomic revision and cladistic analysis of Teratopactus Heller (Coleoptera: Curculionidae). Invertebr Syst 20:585-602

Guedes JVC, Lanteri AA, Parra JRP (2005) Chave de identificação, ocorrência e distribuição dos curculionídeos das raízes dos citros em São Paulo e Minas Gerais. Neotrop Entomol 34:577-584

Lanteri AA, Guedes JC, Parra JRP (2003) Weevils injurious for roots of citrus in São Paulo state, Brazil. Neotrop Entomol 31:561-569

Lanteri AA, Marvaldi AE, Suárez SM (2002) Gorgojos de la Argentina y sus plantas huéspedes. Tomo I: Apionidae y Curculionidae. Sociedad Entomológica Argentina, San Miguel de Tucumán, 98p. (Publicación Especial $n$ 1)

McCoy CW, Duncan LW, Quintela ED (1996) A review of IPM strategies for citrus root weevils with emphasis on microbial control. Proc Int Soc Citric 1:638-641

Quintela ED, McCoy CW (1998) Synergistic effect of two entomopathogenic fungi and imidacloprid on the behavior and survival of larvae of Diaprepes abbreviatus (Coleoptera: Curculionidae) in soil. J Econ Entomol 91:110-122

Silva AA, Gonçalves CR, Galvão DM, Gonçalves AJL, Gomes J, Silva MN, Simoni L (1968) Quarto catálogo dos insetos que vivem nas plantas do Brasil, seus parasitos e predadores, insetos, hospedeiros e inimigos naturais. Parte II Tomo I. Ministério da Agricultura, Rio de Janeiro, 622p 